\title{
AN ANALYSIS OF THE APPROPRIATE MANAGEMENT SYSTEM FOR FUEL ENTERPRISES ${ }^{1}$
}

Bouasaveng MANIKHONG ${ }^{2}$

\section{ABSTRACT}

This case study is aimed to study 1) Environmental factors that affect the analysis and management planning. 2) Competitiveness in business environment. 3) Potential strengths and weaknesses in expanding business. 4) Partner needs. 5) Infrastructure which directly affects business analytics and planning in accordance with the main factors and 6) Lao people's knowledge and skills that influence the management system of the organization by using quantitative study. The quantitative study is in the form of modalities, in which the questionnaires are used as a tool to analyze the samples of 16 fuel companies in Lao PDR (From 27 companies, there are 2 companies that will be closed due to business practice that were inconsistent with the Lao law as well as in 2016, there are 8 new companies which are licensed by the government but the business is still not formal and steady, and yet, 16 companies were still continued to operate their business for a while in Lao PDR). The relationship format consists of 6 independent variables and 4 dependent variables which analyzes data with a statistical endpoint for the integration of variables. The result shows that Structural Equation Model has a relationship with independent variables that influences business planning and setting up management system in accordance with business's target needs and employees can use as a guideline to follow their work instructions as well as understand their work performance in order to carry out its work and well-planned to achieve the company business goals as well as the benefits they will get in the future.

Keywords: Relationship Structure, Business Environment, Employment Knowledge, Business Goals JEL Codes: D22, L22, M12

\section{PETROL KURULUŞLARI İÇİN UYGUN YÖNETİM SİSTEMLERİNIN ANALİİ}

ÖZ

Bu vaka çalışması 1) Yönetim planını ve analizini etkileyen çevresel faktörleri 2) İş çevresindeki rekabeti

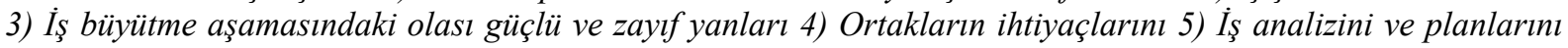
ana faktörlerle uyumlu bir biçimde ve direct olarak etkileyen altyapıyı ve 6) Laos halkının örgütlerin yönetim sistemlerini etkileyen bilgi birikimi ve yeteneklerini nicel analiz vasıtastyla ölçmeyi amaçlamaktadır. Nicel analiz, Laos Demokratik Halk Cumhuriyetindeki 16 petrol kuruluşunu analiz etmek amacıyla anket formu şeklinde uygulanmıştır (27 kuruluştan 2 'si, Laos yasalarına uygun olmadıkları gerekçesiyle kapanmak üzeredir, 8 kuruluş hükümet tarafindan lisanslı olmasına rağmen henüz resmi değildir ve dolaylsiyla 16 tanesi aktif olarak faaliyet göstermektedir). 6 bă̆ımsız 4 bağımlı değişken, tüm değişkenlere ait verilerin entegrasyonunu istatistiksel olarak analiz etmektedir. Elde edilen veriler, Yapısal Eşitlik Modelinin örgütün hedefleriyle uyumlu bir biçimde iş planı ve yönetim sistemi oluşturmayla ilişkili olduğunu; bununla beraber çalışanların bu çıktıları hem bir rehber olarak kullanabileceğini, hem bireysel iş performanslarını tespit edebileceklerini hem de ileride elde edebilecekleri faydaları belirleyebileceklerini ortaya koymuştur.

Anahtar Kelimeler: İlişki Yapısı, Örgüt Çevresi, Mesleki Bilgi, Örgütsel Hedefler

JEL Kodlart: D22, L22, M12

\footnotetext{
1 This article is presented "The 4th International Conference on Management, Business, and Economics \& The 6th International Conference on Tourism, Transport, and Logistics Congress"

${ }^{2}$ DBA Student, Sripatum University, Bangkok-Thailand, veng_b@yahoo.com
} 


\section{INTRODUCTION}

Lao PDR, located in a centered of Indo-China, is a landlocked country which has borders China on the north, Cambodia on the south, Vietnam on the east, Thailand and Myanmar on the west. Previously, Lao PDR was colonized by various countries for more than a hundred years and in 1975 it was released as an independent country. The Lao PDR is subsequently governed by a single party. Between 1975-1987, Laos was a close country. However, in 1988, Lao PDR changed their point of view and welcomed foreign countries to invest in Laos which lead to economic growth in Lao PDR. In 1988, Lao PDR earned 4,08 Billion USD as an income of Gross Domestic Product (GDP), in 2016, Lao PDR has earned more than 15,90 billion USD (As a reference of Trading Economics https://tradingeconomics.com/lao/gdp). An average of Economic growth in Lao PDR has been 7\% per year since 1990-2015 (As a reference of the report of World Bank; https://data.worldbank.org/indicator/NY.GDP.MKTP.KD.ZG?locations=BRLAXname_desc= fa/se).

Lao PDR is one of the economies that have developed well in comparison with the other economic growth rates of other countries in the region. But the economic growth of Lao PDR is also quite sensitive, as the majority of national income is mainly derived from the sale of natural resources and electricity. The Lao PDR has a total area of $236,800 \mathrm{~km} 2$, which the area of the steep hill is about $70 \%$ of the total area and the plains that can produce the agriculture, but still there are many unexploded bombs.

Besides, SME units is comprised 99,8 (126,717) \% of all business and large 196 firms 0.2\% (Source: Policy and Progress in small medium enterprises in Laos, Lao-Japan Human Resources Development institute national university of Laos, June 2010; www.ascam.org), which create jobs for Lao people 286,575 (83\%) for each year. But still, about 7-8\% business units have to be shut down every year due to external conditions, competitiveness, financial problems and internal management within the organization, which is due to the quality of skilled personnel.

In 2016, there were 27 fuel companies operating in Laos, but 2 companies had to be shut down in 2017, as well as other 7 companies ( 2 of them are state enterprises) that were in a difficult situation (Source: Lao nation Chamber log commerce and industry; Petroleum group Association). The main problem is that most of the companies have weak internal management system, which makes them weakness in the efficiency of market expansion and the competition in the fuel business. Based on these factors, the authors have studied the management model of the Lao fuel business as a guide to improve the efficiency of internal management, besides of 
all fuel business could use it as a guide and improve their management system, as well as other business units.

Every single organizational management has an art which is uniquely and scientifically aligned with the nature of the business organization model in Lao PDR. Most of it comes from the transfer from one generation to another generation and from self-study. In business management in the Lao PDR, especially in the fuel business, there was no specific principle of Education teaching from the National University. Another reason was that the professors couldn't convey the knowledge as well as it should be, the convey was based on the essence. Due to the actual experience is limited and superficial, it leads to the organizational management system of the Lao PDR stand in the general point of view, and lack of science as a starting point for business planning in order to achieve business goal, organizational structure, create and control the quality of product and service, personnel recruiting and development, performance monitoring, strategic planning, competition and marketing models, create a handbook, policy and regulatory frameworks, and effective analysis.

The study aims to find the appropriate management for Lao fuel business to provide an appropriate guide in accordance with the culture of business administration in Lao PDR and the scientific conditions in corporate governance. The objective is to study the management system to suit with business environment by improving behavior in accordance with the knowledge, ability, patience, responsibility and honesty in the operation of Lao employment in the fuel business.

\section{SCOPE OF THE STUDY}

Tools and guidelines of organizational management efficiently according to the effective potential and values of Lao workers compared with a scientific fact in the structure of executive corporate relations and support one another to become strength in business planning. According to the research of Philbin, Mallo, activities encouragement could drive a business plan and achieve the target efficiently according to the theory of Jose (José Fernandez-Serrano, 2013).

This study aims to study the linkages through a literature review to identify the causes and factors affecting the link between factors that arise from the environmental changes that affect the operation of oil in Lao PDR (ANTONIOS GEORGOPOULOS, 2014), especially regional conflicts, corruption, warfare, closure of trade routes, confining of fuel, financial suppression and so on in the region. In addition, it is important to consider about internal factors which could affect business operations, such as changes in public policy towards fuel business, promotion of public business operations, domestic unrest, economic growth, population 
receipts, fuel demand, and changes in fuel prices and so on, as well as competitive changes such as technology, transportation, production, supply, business control and so on, which the fuel business entities have to adjust their strategies to be consistent with the competition situation according to the research of Ravipreet (Ravipreet S. Sohi, 2011). Besides these factors, the study of the potential of the area is also important according to Justus (Justus Haucap, 2017). Because entrepreneurs are able to assess business possibilities, it is important to look for customer needs, which are critical to business success. Because the entrepreneur can build a product and service to meet the needs of customers, enabling business operators to take advantage and meet the real needs of their customers according to the research of Nicoleta (Lee Pugalis, 2017) and the skillfulness of trained staff from Lao PDR's educational institutions and the unique culture of individuals, is a factor that can help the organization's performance reach its goals according to the research of Geraldine (Geraldine Kennett, 2013).

Variables that can be observed is the place to control, the process run strictly from the analysis of possible locations, to expand your business, contact targeting, identify vision, organizational structure, job descriptions, to improve personnel skills in accordance with the responsibility, to monitor the results of operations of various units regularly, to estimate the result, to determine the motive.

\section{CONCEPT AND RELATED THEORY}

According to articles of Justin Joy and T. Nambirajan (2016), the requirement analysis highlighted the need for orderly storing. The system was designed and developed using a database management system. The implemented system automated some of the manual processes of the company. The study highlighted the deterring factors that would affect the long term sustenance of the implemented system. This article has laid down parameters to address these hindering factors and has attributed the success of system implementation to an earlier model adapted. Alan Clardy (2013) also mentiones that employees may spend their time on the job behaving in a variety of ways. The purpose of a well-designed performance management system should be to channel and motivate employees to concentrate their energies on valueadded performance. The extent to which an organization achieves this outcome, depends upon the design and structure of its performance management system. The basic framework of any performance management system as presented here, involves four levels of operations, policies, and practices: (1) executive leadership; (2) the infrastructure of strategy, measurement and control, and work process; (3) human resource policies and practices in attracting, hiring, developing, and compensating employees; and (4) workplace working conditions shaped and 
driven by the practices of managers and supervisors and the dynamics of the work group or team. The issues that performance improvement specialists need to consider in analyzing an organization's performance management system are noted.

\section{Variations from compiling and analysis that affect business performance}

From the analysis and compilation of economic data from the region and the country where the enterprise is located, it is important because the source of raw materials is from abroad, if the economic situation of raw material suppliers is caused by economic problems, war, internal unrest, trade barriers, disaster and other which could affect the purchasing, transportation, and changes in the economy, which affect the purchasing power or regulatory circumstance that can affect business, transportation, money exchange and so on.

From a revision of the literature, the researcher shows analyzes data on economic growth, development, trade disputes, warfare, economic sanctions in the region and in the country, it is necessary to know the tendency of business reflection and to adjust their business practices according to their circumstances. 
Table 1: Environmental Factors

\begin{tabular}{|c|c|c|}
\hline Researcher & Topics & Importance of information \\
\hline $\begin{array}{l}\text { P.Pegkas and } \\
\text { C.Tsamadias, } 2016\end{array}$ & $\begin{array}{l}\text { How important are foreign and } \\
\text { domestic investments, exports and } \\
\text { human capital for Greece's economic } \\
\text { growth? }\end{array}$ & $\begin{array}{l}\text { The empirical analysis reveals that there is } \\
\text { evidence of unidirectional long-run and short run } \\
\text { Granger causality running from foreign direct and } \\
\text { domestic investments, exports and human capital } \\
\text { to economic growth; and that there is a positive } \\
\text { effect, in the long-run, of all determinants on } \\
\text { economic growth. The contribution size of these } \\
\text { economic variables, especially of foreign direct } \\
\text { investment, is probably not adequate and } \\
\text { sufficient to bring the Greek economy back to } \\
\text { growth. }\end{array}$ \\
\hline $\begin{array}{l}\text { Yanni Yan, Daniel Ding } \\
\text { \& Simon Mak, } 2009\end{array}$ & $\begin{array}{l}\text { The impact of business investment } \\
\text { on capability exploitation and } \\
\text { organizational control in } \\
\text { international strategic alliances }\end{array}$ & $\begin{array}{l}\text { The results of this study shed light on how } \\
\text { international strategic alliances (ISA) operating in } \\
\text { an environment like China are able to improve } \\
\text { their business investments in both capital and non- } \\
\text { capital resources. Organizational capability in } \\
\text { terms of management-, marketing- and } \\
\text { technology-specific capabilities in this study is as } \\
\text { a distinctive construct and the result of this study } \\
\text { suggests that the establishment of business targets } \\
\text { can positively moderate the relationship between } \\
\text { a firm's business investment and organizational } \\
\text { capabilities. The assessment of the multiplicity of } \\
\text { the forms of organizational capabilities draws } \\
\text { attention to the capability dimensions that enable } \\
\text { ISAs to adapt to changing market conditions }\end{array}$ \\
\hline $\begin{array}{l}\text { Jelena Stankeviciene } \\
\text { Tatjana Sviderske } \\
\text { Algita Miecinskiene, } 2014\end{array}$ & $\begin{array}{l}\text { Comparison of country risk, } \\
\text { sustainability and economic safety } \\
\text { indices }\end{array}$ & $\begin{array}{l}\text { country risk, sustainability and economic safety } \\
\text { could be used to evaluate and standardize country } \\
\text { risk, sustainability, and economic safety as a ratio } \\
\text { system, reference point and multiplicative form } \\
\text { appropriately suitable for cases, where there are } \\
\text { several alternatives (EU countries or the Baltic } \\
\text { States), and several objectives. }\end{array}$ \\
\hline Cliff Ferguson, 2017 & $\begin{array}{l}\text { Business continuity and disaster } \\
\text { management within the public service } \\
\text { in relation to a national development } \\
\text { plan }\end{array}$ & $\begin{array}{l}\text { The Disaster Management Framework and the } \\
\text { National Development Plan, linking these to } \\
\text { Business Continuity Management, through a } \\
\text { resilience period model, as a means for the } \\
\text { implementation of resilience strategies. The goals } \\
\text { of the National Development Plan are outlined with } \\
\text { a view to how resilience can be achieved in each. A } \\
\text { resilience period model has been advocated for the } \\
\text { implementation of projects within the public sector } \\
\text { in order to provide continuity and sustainability }\end{array}$ \\
\hline
\end{tabular}

\section{Variations from compiling and analysis of competition in business}

Analyzing and compiling information on business competitiveness of the same country

is important because it will be possible to compare the marketing tactics that are used for maximizing customer satisfaction in order to achieve sale's target.

From the Literature review, the researchers show that the analysis of business strategy is important to keep the business stable and to grow steadily or to collapse, which strategy the competition used, building market activities, use of business or other services to attract 
customers to services, production, administration, innovation, new business development, area monopoly, credit or other privileges to customers.

\section{Table 2: Competition Condition}

\begin{tabular}{|c|c|c|}
\hline Researcher & Topics & Importance of information \\
\hline $\begin{array}{l}\text { L. Szasz, 2012, Issue 4, } \\
\text { p180-187. 8p }\end{array}$ & $\begin{array}{l}\text { Patterns of change of } \\
\text { manufacturing competitive } \\
\text { priorities and competitive } \\
\text { capabilities }\end{array}$ & $\begin{array}{l}\text { Results of the study suggest that in order to } \\
\text { reach high business performance, } \\
\text { manufacturing companies need to develop } \\
\text { agile strategies and react quickly to changes } \\
\text { in customer preferences. Companies aiming } \\
\text { to maintain a proper importance- } \\
\text { performance fit of competitive factors are } \\
\text { more likely to reach higher business } \\
\text { performances. The longitudinal analysis of } \\
\text { importance-performance fit improvement } \\
\text { provides support for both the cumulative } \\
\text { capabilities and the trade-off theory, i.e. the } \\
\text { integrative model. }\end{array}$ \\
\hline L.P. Krüger, 2012 & $\begin{array}{l}\text { Developing operations strategies - } \\
\text { reassessing the strength and } \\
\text { importance of competitive } \\
\text { operations priorities for South } \\
\text { African businesses }\end{array}$ & $\begin{array}{l}\text { The results suggest that South African } \\
\text { businesses, which have developed an } \\
\text { operations capability that simultaneously } \\
\text { offers higher quality products and/or services } \\
\text { at a lower cost and on a more dependable } \\
\text { basis than its competitors do, hold the most } \\
\text { promise for success in the future business } \\
\text { environment locally and internationally. }\end{array}$ \\
\hline $\begin{array}{l}\text { Janis priede, Roberts } \\
\text { Škapars, } 2009\end{array}$ & $\begin{array}{l}\text { Quality competitiveness of Latvia } \\
\text { and strategy to improve it }\end{array}$ & $\begin{array}{l}\text { Issues of competitiveness always have been } \\
\text { important for countries and companies. Global } \\
\text { Competitiveness Report is the most } \\
\text { recognizable competitiveness comparison. } \\
\text { This report shows that Latvia's weakest pillars } \\
\text { are Business sophistication and Innovations. } \\
\text { Karl Aiginger's method uses unit value of } \\
\text { exports to comparison quality competitiveness } \\
\text { of countries }\end{array}$ \\
\hline $\begin{array}{l}\text { Larry Dwyer } \\
\text { Tanja Armenski } \\
\text { Ljubica Knezevic Cvelbar } \\
\text { Vanja Dragicevic } \\
\text { and anja Mihalic, } \\
2015\end{array}$ & $\begin{array}{l}\text { Modified importance-performance } \\
\text { analysis for evaluating tourism } \\
\text { businesses strategies: comparison } \\
\text { of Slovenia and Serbia }\end{array}$ & $\begin{array}{l}\text { An important finding is that respondents in } \\
\text { each country allocated the bulk of activities to } \\
\text { the 'keep up the good work' strategy. In both } \\
\text { destinations, this strategy was dominated by } \\
\text { activities related to product development and } \\
\text { innovation. The paper concludes with a } \\
\text { discussion of how the identified priority } \\
\text { activities require close examination to } \\
\text { determine their 'enabling conditions' and the } \\
\text { implications of an action based on them. }\end{array}$ \\
\hline
\end{tabular}

\section{Variables from compiling and analyzing potential data as business factors}

From analysis and compilation of potential business opportunities, it is important for business decision-making.

From a review of the literature of the researchers show the analysis of business potential information is important in determining the size of the business to calculate the number of commercial requirements, the location is convenient and safe, delivery of goods, and so on. 
Table 3: Business Potential

\begin{tabular}{|c|c|c|}
\hline Researcher & Topics & Importance of information \\
\hline Peter V. Miller, 2017 & Is there a future for surveys? & $\begin{array}{l}\text { The survey data may increasingly be one } \\
\text { component of information products, formed from } \\
\text { various sources, including administrative records } \\
\text { and unstructured ("big") data. The papers in this } \\
\text { special issue of Public Opinion Quarterly will } \\
\text { contribute to discussions on how future surveys } \\
\text { should be conducted and their place in a new } \\
\text { information order }\end{array}$ \\
\hline $\begin{array}{l}\text { Andrew W. Mercer } \\
\text { Frauke Kreuter } \\
\text { Scott Keeter } \\
\text { Elizabeth A. Stuart, } \\
2017\end{array}$ & $\begin{array}{l}\text { Theory and practice in } \\
\text { nonprobability surveys }\end{array}$ & $\begin{array}{l}\text { It is one thing to know in principle that exchange } \\
\text { ability, positivity, and composition must be } \\
\text { achieved in order to avoid selection bias in } \\
\text { nonprobability survey estimates. It is another } \\
\text { thing to achieve them successfully in practice. } \\
\text { Even when the subject matter is well known and } \\
\text { many likely confounders are identified, it may } \\
\text { prove difficult to have complete confidence that } \\
\text { there is not some yet unknown factor quietly } \\
\text { introducing bias into survey estimates. } \\
\text { Nevertheless, by making explicit a set of } \\
\text { assumptions that to date have been largely } \\
\text { implicit, the notions of exchangeability, } \\
\text { positivity, and composition provide a } \\
\text { framework by which to evaluate and critique } \\
\text { specific research findings and improve } \\
\text { methodological practice }\end{array}$ \\
\hline Sharon Poczter, 2018 & $\begin{array}{l}\text { Business Groups in Emerging } \\
\text { Markets: A Survey and } \\
\text { Analysis }\end{array}$ & $\begin{array}{l}\text { The existing literature on business groups is } \\
\text { voluminous and multidisciplinary, but the } \\
\text { essential qualifying characteristics and welfare } \\
\text { effects of business groups remain unclear and to } \\
\text { a large extent unknown, even as the global } \\
\text { economic significance of such groups continue to } \\
\text { grow. By bringing some of the relevant } \\
\text { literature's most problematic aspects to the fore, } \\
\text { this article aims to make this vast body of } \\
\text { research more approachable to academics and } \\
\text { practitioners alike, as well as to contribute to the } \\
\text { establishment of a common foundation for future } \\
\text { work }\end{array}$ \\
\hline
\end{tabular}

\section{Variables from compiling and analyzing customer needs information}

From the analyzing and compiling data, it is necessary to understand the needs of the customer so that the organization can improve the supply and demand of the customers.

Customers' needs are different, with each group having a different need to use their goods to satisfy their needs, such as quality and quantity, service, convenience, attention, security of life and property, and so on. 
Table 4: Customers' Needs

\begin{tabular}{|c|c|c|}
\hline Researcher & Topics & Importance of information \\
\hline $\begin{array}{l}\text { Michael A. Jones and } \\
\text { Valerie A. Taylor, } 2014\end{array}$ & $\begin{array}{l}\text { The effect of requests for } \\
\text { positive evaluations on customer } \\
\text { satisfaction ratings }\end{array}$ & $\begin{array}{l}\text { The indicate that the request for positive } \\
\text { evaluation has a negative influence on } \\
\text { customers repurchase intentions and } \\
\text { positive word-of-mouth intentions, but only } \\
\text { for customers who had a more internal locus } \\
\text { of control compared to those with a more } \\
\text { external locus of control. }\end{array}$ \\
\hline $\begin{array}{l}\text { Brent Kitchens, David } \\
\text { Dobolyi, Jingjing Li, and } \\
\text { Ahmed Abbasi, } 2018\end{array}$ & $\begin{array}{l}\text { Advanced customer analytics: } \\
\text { strategic value through } \\
\text { integration of relationship- } \\
\text { oriented big data }\end{array}$ & $\begin{array}{l}\text { The analysis move beyond siloed } \\
\text { transactional customer analytics approaches } \\
\text { of the past and incorporate a variety of rich, } \\
\text { relationship-oriented constructs to provide } \\
\text { actionable and valuable insights. We develop } \\
\text { a customized kernel-based learning method } \\
\text { to take advantage of these rich constructs and } \\
\text { instantiate the framework in a novel } \\
\text { prototype system that accurately predicts a } \\
\text { variety of customer behaviors in a } \\
\text { challenging environment, demonstrating the } \\
\text { framework's ability to drive significant } \\
\text { value. }\end{array}$ \\
\hline $\begin{array}{l}\text { Nicoleta Valentina Florea, } \\
\text { Anisoara Duica, } 2017\end{array}$ & $\begin{array}{l}\text { Improving communication and } \\
\text { relationship with customers } \\
\text { using models to measure their } \\
\text { value }\end{array}$ & $\begin{array}{l}\text { If we could know what is in the mind of } \\
\text { consumers, we would know what to offer } \\
\text { them with a minimum consumption of } \\
\text { resources and maximum profitability; but } \\
\text { because we do not know these aspects, } \\
\text { related to the clients' desires, their needs, } \\
\text { which are changing continuously, then } \\
\text { organizations can implement certain } \\
\text { models that can help organizations to } \\
\text { measure value, the value required to invest } \\
\text { in this relationship and to know which are } \\
\text { the most valuable and loyal consumers. } \\
\text { This is necessary to provide them with } \\
\text { information, in order to offer discounts, } \\
\text { deals and new products and services, in } \\
\text { order to attract new clients and retain } \\
\text { existing ones }\end{array}$ \\
\hline
\end{tabular}

\section{Variation from compiling and data infrastructure analysis}

From the analysis and compiling data, the data infrastructure is necessary to establish a

business, transport, human resources, skills development, natural disaster, tools and so on.

Data infrastructure means: the right way of transporting goods to customers at any time, transportation vehicles, communications, trade, supply, and money transfers, and so on. 
Table 5: Infrastructure

\begin{tabular}{|l|l|l|}
\hline \multicolumn{1}{|c|}{ Researcher } & \multicolumn{1}{|c|}{ Topics } & \multicolumn{1}{c|}{ Importance of information } \\
\hline $\begin{array}{l}\text { Olaf Jonkeren and Piet } \\
\text { Rietveld, 2016 }\end{array}$ & $\begin{array}{l}\text { Protection of critical waterborne } \\
\text { transport infrastructures: an economic } \\
\text { review }\end{array}$ & $\begin{array}{l}\text { We find that in a number of cases market forces exist } \\
\text { to take the appropriate protection measures. One of } \\
\text { the problems is that the risks of natural hazards, } \\
\text { major calamities, piracy and terrorism are difficult to } \\
\text { assess and as long as these risks are low and } \\
\text { uncertain, a tendency may be expected that they are } \\
\text { ignored by private parties. An important role for } \\
\text { public authorities is therefore to define liabilities and } \\
\text { generates reliable information on these risks. We } \\
\text { find, however, that also with better information there } \\
\text { are a good number of market failures. }\end{array}$ \\
\hline $\begin{array}{l}\text { Marta Cudzilo, Roksolana } \\
\text { Voronina, Davor Dujak, Adam } \\
\text { Kolinski, 2018 }\end{array}$ & $\begin{array}{l}\text { Analyzing the efficiency of logistics } \\
\text { actions in complex supply chain - } \\
\text { conceptual and methodological } \\
\text { assumptions of research }\end{array}$ & $\begin{array}{l}\text { The study resulted in the development of the } \\
\text { concept concerning the performance of efficiency } \\
\text { analyses focused on logistic actions, the } \\
\text { particular elements of which have been verified } \\
\text { in terms of their usefulness in economic practice. }\end{array}$ \\
\hline \multicolumn{2}{|c|}{}
\end{tabular}

\section{Variations from compiling and analysis of employee's expertise}

From analyzing and compiling data on the level of employees' expertise in a specific

business, it is important that to implement the plan to achieve the goals of the organization, the employees is important to carry out the tasks that assigned to them.

A talent, responsibility, enthusiasm for the job, innovation, honesty, and patience and so on is a unique culture of Lao people that is also important to carry out the work to achieve the objectives of the organization.

Table 6: Employee Expertise

\begin{tabular}{|l|l|l|}
\hline \multicolumn{1}{|c|}{ Researcher } & \multicolumn{1}{|c|}{ Topics } & \multicolumn{1}{c|}{ Importance of information } \\
\hline $\begin{array}{l}\text { Ans De Vos } \\
\text { Willemse,2015 }\end{array}$ & $\begin{array}{l}\text { An integrative model for competency } \\
\text { development in organizations: } \\
\text { the Flemish case }\end{array}$ & $\begin{array}{l}\text { The prominent role of competency development in } \\
\text { enhancing the success of employees and organizations } \\
\text { has drawn the attention of practitioners leading them to } \\
\text { introduce competency development as a central part of } \\
\text { their human resource practices. } \\
\text { Unfortunately, this strong managerial interest has not } \\
\text { been fully translated into the academic world, creating } \\
\text { a gap between theory and practice }\end{array}$ \\
\hline Matej Jevšcek, 2016 & $\begin{array}{l}\text { Competencies assessment using fuzzy } \\
\text { logic }\end{array}$ & $\begin{array}{l}\text { An example of an »Initiative« competency evaluation } \\
\text { model is created and tested in the research study. } \\
\text { Testing confirmed that evaluation using fuzzy logic is } \\
\text { efficient. }\end{array}$ \\
\hline $\begin{array}{l}\text { Gudivada Venkat Rao \& } \\
\text { D.Vijayalakshmi, 2016 }\end{array}$ & $\begin{array}{l}\text { Competencies for building performance } \\
\text { excellence: a study in a fertilizer unit }\end{array}$ & $\begin{array}{l}\text { Competency has a wide meaning and includes } \\
\text { knowledge, abilities, skills and behavior exhibited in } \\
\text { accomplishing a task. Competency mapping is a tool } \\
\text { for mapping the competencies required for executing } \\
\text { roles or jobs. The identification and fixing of } \\
\text { competencies differ according to the nature of the } \\
\text { organization }\end{array}$ \\
\hline
\end{tabular}


From a review of the relevant documents, it is possible to express are lationship in the Conceptual Flame Work as below:

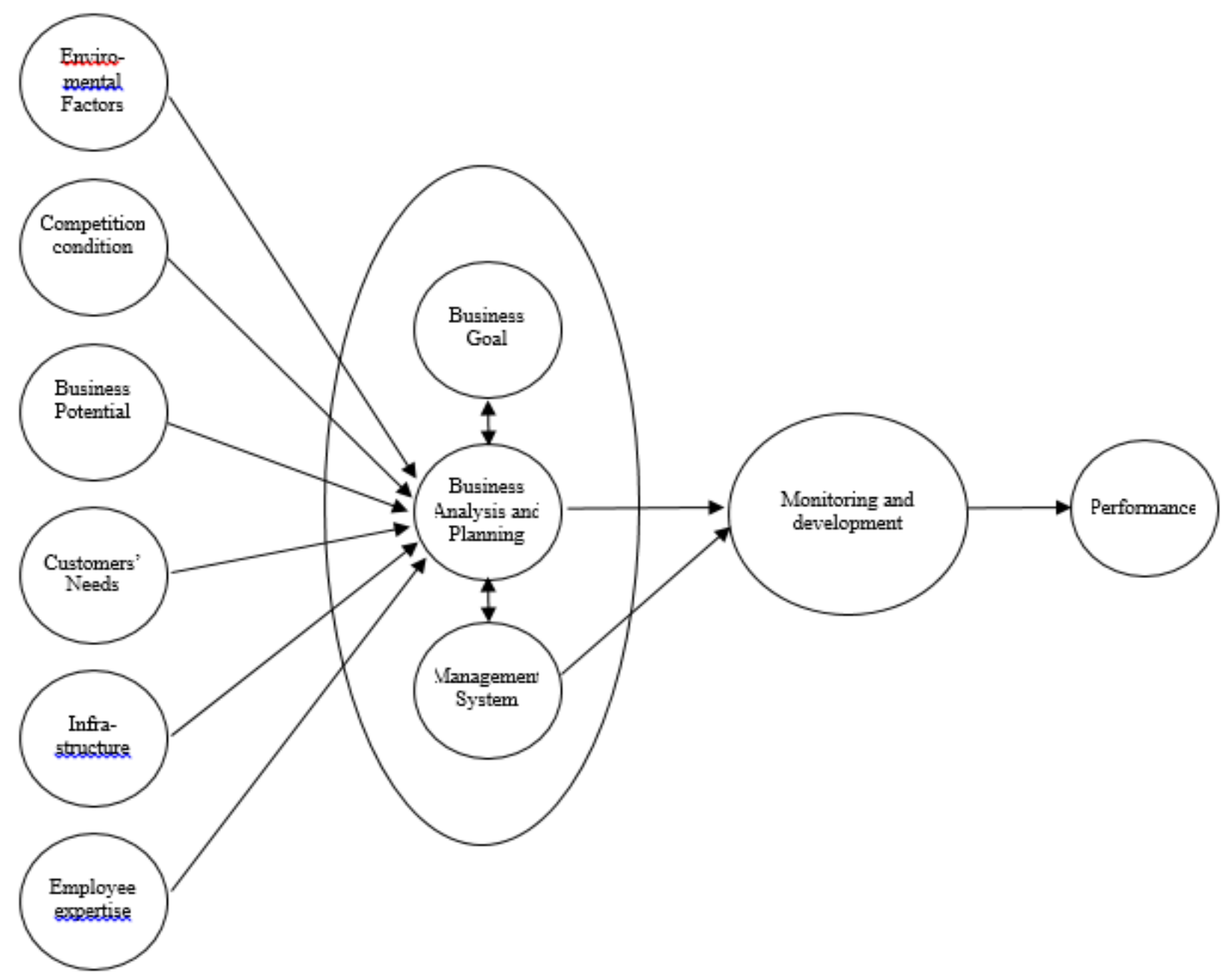

Figure 1: Relationship In Building Corporate Governance

The researcher has set the Conceptual Flame Work as an example below:

X1 - Business Environmental Factors

X2 - Competition condition

X3 - Business Potential

X4 - Customers' Needs

X5 - Infrastructure condition

X6 - Employee Expertise

Y1.1 - Business Goal

Y1.2 - Business Analysis and Planning

Y1.3 - Analysis, plan \& Design Management System (Management System)

Y2 - (Monitoring and Development 


\section{RESEARCH METHODOLOGY}

\section{Scopes of population}

Target population in education is the administration of 16 Lao fuel companies.

\section{Location of the survey}

The location for this survey is the head office of the Fuel Companies located in Vientiane, Lao PDR.

\section{Duration of Survey}

Duration of survey was 90 days, started from 01/02/2018 - 03/05/2018.

\section{RESULTS DISCUSSION}

\section{Theoretical assessments and the performance of other interested psychologists}

Management systems are important to the success of a business entity, because any internal strength comes from a system of administration that is consistent with business activities. In addition to helping to ensure that organizational operations are well organized, there is a sense of cooperation, ownership of the project, as a process, saving unnecessary costs due to lack of detailed and non-overlapping planning of action plans according to the case study of Mohammad (Mohammad Danish, 2016). It also serves to ensure that responsibility is properly aligned with the expertise of the units and individuals with specific responsibilities and the goal of the achievement of the project is to be a guide for the project owner to be able to fully implement the timetable and the motivation which could help responsible person to drive the responsibility by enduring all the potential that he or she has got, in order to achieve the target needs as well as a good outcome, and the organization will also achieve the goal (Schoen, 2014).

The cause of the establishment of an enterprise management system in consistent with the business competitiveness and according to the knowledge - the ability and the values of the individual

Lao people have a livelihood by exploiting natural resources into their livelihoods and their families, cultivation, livestock, fisheries, etc., which are often associated with the use of natural resources. Meanwhile, the nation has been occupied and colonized by foreign nations. Throughout the period to be colonized by foreign nations, Laos were not into manufacturing, trading or operating technology, but some were into craftsmanship by using natural raw materials as a household appliances, paintings, pavements, etc, but later on those skilled workers moved to other countries, as mentioned in the book " Former and Current Lao nation " (written by: PhD Phouthong Sengarkhom, established in 2012). After Lao PDR got 
independence in 1975, it has focused on refining the nation from the destruction of the war. In 1986, Lao PDR has welcomed foreign countries to invest in Laos which created a large scale investment business. Due to the economic changes, that is affecting the business model from the past when was the commercialization in the general market, it has been an incentive for Lao people to learn about professional and large business activities, as the they have limited experience and skills in business operations and operating as a family business; but the environment, tactics and technology have changed over time. Therefore, it is essential that business units change their ways and methods of doing business in order to strengthen their competitiveness by combining resources, such as technologies, information and innovations that are appropriate to meet the needs of customers in the business as well as appropriate with the Lao people's knowledge, culture and diligence.

\section{The importance of setting up an enterprise management system in order to be successful}

Due to Lao people are individuals who are taught to graciously recognize parents and perform activities under the supervision of their parents, teachers, or by passing on the culture, they have to perform their duties according to the direction of the commander. The format of this management system had to wait and the orders was made solely by the owner, the executives had to analyze and deal with problems by themselves, even it was a big trouble or not, you are capable or not, because of the lack of accurate information that led to the quality of the work was not achievable. Besides, the executives had to analyze every business activity, and the executives had limited time to plan business in order to achieve the goal and lack of strategy to support the plans to be implemented. As well as the operation was restricted to the extent planned, this previously led to the failure of the business unit to deal with the problem such as the location effect on sales target, causing business units to find financial liquidity problems due to inadequate investment in market demand. Commercial and budget leaks, the quality of goods and services did not meet the standards and suppliers; customers lacked confidence which led to debt obligations, and other problems. These problems might hinder business growing and the current business might face many obstacles.

A good management system could help to drive the operations which have already been analyzed and it is an opportunity to run the business to strengthen as well as business growth in order to guarantee the business process and the activities to achieve the goal, according to the plan by defining the vision which considers as a road map to complete the mission according to the research of Mr. Rachna (Rachna Gulati, 2017). When employees and executives understands the vision, it will help to ensure that the activities of the parties are inclusive and in the same direction. 
The business analysis and business planning to be used as a basis for conducting departmental activities in accordance with the business conditions, duties and responsibilities of each participating entity, utilizing resources, time, budget, according to the strengths of each unit, and improving the weaknesses of the units in facilitating the implementation of the work.

Monitoring and performance indicator are the keys to encourage the activities and run the business plan. In addition, monitoring the progress of operations, also helps to address the problems of other entities within the organization, in order to facilitate the host organization responsible for the task. Identification of indicators is used as an indicator of the degree of success of the organization in the process of approving the plan and reflecting the capacity of the unit, including its recognition of the work of other entities in the organization and it is a reference to the incentive award, as well as the progress of duties as a result of the achievements.

Determining the role and process of operation is very important for the team and employees of the organization to perform activities of their responsibility, because teams and employees can perform their duties within the scope and process which is irrelevant to their knowledgeable skills without worrying about performing duplicate tasks with other entities or any others. This would give employees the confidence to carry out their duties, as well as facilitating the proper functioning of themselves and their capabilities.

The determination of organization Policy and Regulations are made for the purpose of carrying out the work legally, regulatory and morally, as well as the Lao culture, fairness, transparency, respects higher position and those involves in conducting business or any businessmen and any fraudulence in order to take advantage from the company or customers. Company image destruction, organizational breakdown, divisive religions or sexuality, the implementation of the wrongful work of the Lao PDR, besides it also affects related businessmen. The determination of punishment against those who performs intentionally or unintentionally and against the rules of the organization or praising those who have a great effect in performing their duties properly.

\section{DESIGNING MANAGEMENT SYSTEM}

The design of an enterprise management system is to set the direction for employees in the organization, which is the basis for carrying out its work, able to carry out a well-planned, well-evaluated plan to be consistent with the situation as well as evaluate the performance. 
Table 7: Management System

\begin{tabular}{|c|c|c|}
\hline Researcher & Topics & Importance of information \\
\hline Angelo Ditillo, 2012 & $\begin{array}{l}\text { Designing management control systems } \\
\text { to foster knowledge transfer in } \\
\text { knowledge-intensive firms: A network- } \\
\text { based approach }\end{array}$ & $\begin{array}{l}\text { Research on management control has emphasized the } \\
\text { relevance of controls for knowledge integration on a } \\
\text { project-by-project basis. This work contributes to this } \\
\text { field by proposing a framework to explain how } \\
\text { management control systems foster knowledge } \\
\text { transfer between organizational units in knowledge- } \\
\text { intensive firms. By combining network theory and } \\
\text { knowledge network research, this study suggests that } \\
\text { the design of management control systems should } \\
\text { consider various forms of relationships between } \\
\text { individuals (strong/weak, direct/indirect) that these } \\
\text { systems activate and that are necessary to transfer } \\
\text { various forms of knowledge (process, outcome, } \\
\text { technology or opportunities) characterized by } \\
\text { different levels of causal ambiguity and relatedness. }\end{array}$ \\
\hline Terry L. Fox, 2011 & $\begin{array}{l}\text { A systems analysis, design, and } \\
\text { development case study: Williams } \\
\text { Bros. Appliances inventory \& point-of- } \\
\text { sale system }\end{array}$ & $\begin{array}{l}\text { This case study offers students a unique opportunity } \\
\text { to apply the concepts and techniques learned in } \\
\text { systems analysis and design to a realistic and } \\
\text { reasonably-sized project. For systems development } \\
\text { students it provides the opportunity to completely } \\
\text { develop a working system for a relatively common } \\
\text { environment while still offering challenges that } \\
\text { require drawing on skills learned in analysis and } \\
\text { design, database, and programming courses. }\end{array}$ \\
\hline $\begin{array}{l}\text { Kalyan Talluri, } \\
\text { Castejon, Begonando } \\
\text { Juan Magaz,2010 }\end{array}$ & $\begin{array}{l}\text { Proving the performance of a new } \\
\text { revenue management system }\end{array}$ & $\begin{array}{l}\text { A firm considering using a new revenue management } \\
\text { (RM) model or RM system needs to evaluate its } \\
\text { performance. In this article, we describe a 'live' } \\
\text { performance measurement experiment that we } \\
\text { conducted at Iberia Airlines on a set of flights. A set } \\
\text { of competing algorithms control a set of flights during } \\
\text { adjacent weeks, and their behavior and results are } \\
\text { observed over a relatively long period of time ( } \\
\text { months). In parallel, a group of control flights were } \\
\text { managed using the traditional mix of manual and } \\
\text { algorithmic control (incumbent system). Such } \\
\text { 'sandbox' testing, while common in many large } \\
\text { internet search and e-commerce companies, is } \\
\text { relatively rare in the RM area. Sandbox testing has an } \\
\text { undisputable model of customer behavior but the } \\
\text { experimental design and analysis of results is less } \\
\text { clear. }\end{array}$ \\
\hline
\end{tabular}

\section{FURTHER RESEARCH}

Procedures: after the model providing presentation from this research, the further research procedures are as shown in figure.7. The researcher could present the results from the population contexts and samples in order to be the academic and profession benefits. 


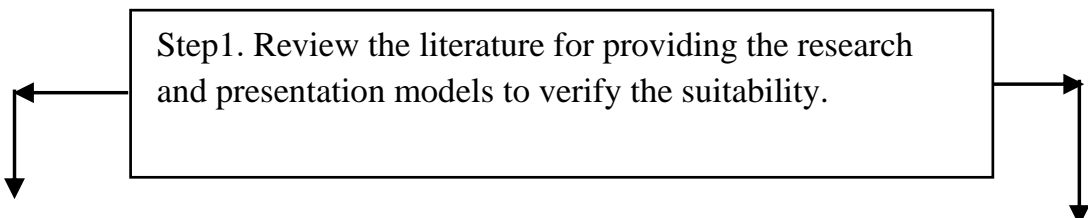

Step 3 Qualitative methods for research variable synthesis.

Step 2. Outline the questionnaires from the literature review.

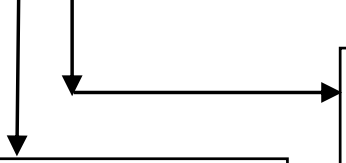

Population: Entrepreneur who Use Technology commercial in Thailand.

Sampling: Purposive sampling technique 7 persons.

Research tool: In-depth interview.

Analysis: Analyze conversation to find out factors that adapted to use in the context of Thailand.
Step 4. .Combined Step 2nd and Step 3rd data to provide the research tools.

Step 5. Test the research tools precision through IOC method.

Step 6. Verify the research tools assurance through Cronbranch's Method.

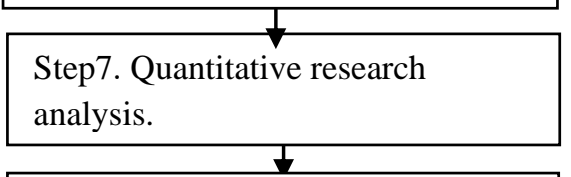

Step8. Quantitative analysis results.

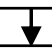

Step9. Quantitative method to insist the result correctness.

Step10. Conclusion, result and discussion, suggestion and presentation.
Population: Employee who Use Technology commercial in Thailand.

Sampling: -

Research tool: Questionnaire.

Analysis: Descriptive and inferential statistics by structure equation modeling (SEM(.

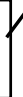

Population: Entrepreneurs and stakeholders commercial in Thailand

Sampling: Purposive sampling technique 7 persons.

Research tool: Focus group.

Analysis: Analyze conversation by content analysis method to confirm result from quantity research. analysis. 


\section{REFERENCES}

A. Georgopoulos Et Al. (2014). "Foreign Versus Domestic Survival In A Changing Environment”, Int. J. Of The Economics Of Business, 2014 Vol. 21, No. 2, 209-229.

Alan Clardy, Phd. (2013). “A General Framework For Performance Management Systems: Structure, Design, And Analysis", Performance Improvement, Vol. 52, No. 2.

Allan H. Church. (2017). "The Art And Science Of Evaluating Organization Development Interventions", Od Practitioner Vol. 49 No. 22017.

Andrew W. Mercer. (2017). “Theory And Practice In Nonprobability Surveys”, Public Opinion Quarterly, Vol. 81, Special Issue, 2017, Pp. 250-279.

Angelo Ditillo. (2012). "Designing Management Control Systems To Foster Knowledge Transfer In KnowledgeIntensive Firms: A Network-Based Approach", European Accounting Review, Vol. 21, No. 3, 425-450, September 2012.

Antonie Van Nistelrooij \& Harry Sminia. (2010). “Organization Development: What's Actually Happening?”, Journal Of Change Management, Vol. 10, No. 4, 407-420, December 2010.

Argerie Vasilakes And Ray Luechtefeld. (2017). "Transforming Ourselves To Transform Our Organizations”, Od Practitioner Vol. 49 No. 42017.

Brent Kitchens, David Dobolyi, Jingjing Li, And Ahmed Abbasi. (2018). "Advanced Customer Analytics: Strategic Value Through Integration Of Relationship-Oriented Big Data”, Journal Of Management Information Systems / 2018, Vol. 35, No. 2, Pp. 540-574.

Chia-Lin Chen And Roger Vickerman. (2017). "Can Transport Infrastructure Change Regions' Economic Fortunes? Some Evidence From Europe And China”, Regional Studies, 2017, Vol. 51, No. 1, 144-160.

Cliff Ferguson. (2017). "Business Continuity And Disaster Management Within The Public Service In Relation To A National Development Plan”, Journal Of Business Continuity \& Emergency Planning, Vol. 11, No. 3, Pp. 243-255.

Cliff Ferguson. (2017). "Business Continuity And Disaster Management Within The Public Service In Relation To A National Development Plan”, Journal Of Business Continuity \& Emergency Planning Volume 11 Number 3.

Cudziło M, Voronina R, Dujak D, Koliński A. (2018). “Analyzing The Efficiency Of Logistic Actions In Complex Supply Chains - Conceptual And Methodological Assumptions Of Research”. Logforum 14 (2), 171-184.

D.D. Warrick. (2014). "What Leaders Can Learn About Teamwork And Developing High Performance Teams From Organization Development Practitioners", Od Practitioner, Vol. 46 No. 32014.

Dave Hanna. (2010). “Organization Development And Human Resources Management”, Od Practitioner, Vol. 42 No. 42010.

Dave Hanna. (2010). “Organization Development And Human Resources Management”, Od Practitioner, Vol. 42 No. 42010.

E. Ustundagli - M. Baybars - E. B. Guzeloglu. (2015). "Collaborative Sustainability: Analyzing Economic And Social Outcomes In The Context Of Cittaslow”, Business And Economics Research Journal, Pp. 125144.

Edward E. Lawler Iii. (2014). "Sustainable Effectiveness And Organization Development", Od Practitioner Vol. 46 No. 42014.

G. Tomas M. Hult \& Claes Fornell \& Forrest V. Morgeson Iii \& Neil A. Morgan \& Sunil Mithas. (2017). "Do Managers Know What Their Customers Think And Why?”, J. Of The Acad. Mark. Sci. (2017) 45:37-54.

Hindy Lauer Schachter. (2017). "Organization Development And Management History: A Tale Of Changing Seasons"

J. Stankeviciene Et Al. (2014). "Comparison Of Country Risk, Sustainability And Economic Safety Indices"

Janis Priede And Roberts Škapars. (2009). "Quality Competitiveness Of Latvia And Strategy To Improve It”, Issue 1822 - 8402 European Integration Studies. 2009. No 3.

Jasenko Ljubica, Želimir DulčIć, Ina Aust. (2016). "Linking Individual And Organizational Cultural Competences: One Step Closer To Multicultural Organization”, Management, Vol. 21, 2016, Special Issue, Pp. 51-82.

Juan A. Manez. (2015). “The Determinants Of R\&D Persistence In Smes”, Small Bus Econ (2015) 44:505-528.

Justin Joy And T. Nambirajan. (2016). "Resource Tracking And Planning System Project: An Adapted Implementation Model”, Scms Journal Of Indian Management, April - June 2016.

Kalyan Talluri, Fernando Castejon, Begona Codina And Juan Magaz. (2010). "Proving The Performance Of A New Revenue Management System"

Keng Siau \& Matti Rossi. (2011). "Evaluation Techniques For Systems Analysis And Design Modeling Methods - A Review And Comparative Analysis”, Info Systems J (2011) 21, 249-268.

Kinjal Shukla , Nidhi Heda , Rasananda Panda . (2015). "Implications Of Organization Development Interventions: Case Study Of An Edible Oil Company”, Review Of Management, Vol. 5, No. 1/2, June 2015 . 
L. Dwyer Et Al. (2016). "Modified Importance-Performance Analysis For Evaluating Tourism Businesses Strategies: Comparison Of Slovenia And Serbia", International Journal Of Tourism Research, Int. J. Tourism Res., 18: 327-340.

L. Szász . (2012). "Patterns Of Change Of Manufacturing Competitive Priorities And Competitive Capabilities"

L.P. Krüger. (2012). "Developing Operations Strategies - Reassessing The Strength And Importance Of Competitive Operations Priorities For South African Businesses", South African Journal Business Management.

Mark Grysiuk. (2016). "Conducting A Business And Systems Analysis To Protect Your Ecm Investment”

Mark J. Koetse And Piet Rietveld (2012). "Adaptation To Climate Change In The Transport Sector”, Transport Reviews, Vol. 32, No. 3, 267-286.

Martin Goldberg And Claudy Jules. (2010). "Organization Development And Human Resources”, Od Practitioner, Vol. 42 No. 42010.

Mee-Yan Cheung-Judge. (2017). "Future Of Organizations And Implications For Od Practitioners", Od Practitioner, Vol. 49 No. 12017.

Michael A. Jones And Valerie A. Taylor. (2014). "The Effect Of Requests For Positive Evaluations On Customer Satisfaction Ratings"

Michelle Heyne, Robert Gallagher, Joaneileen Coughlan, And Martha Lewin. (2016). "Quality \& Empowerment”, Od Practitioner Vol. 48 No. 22016.

Michelle Heyne, Robert Gallagher, Joaneileen Coughlan, And Martha Lewin. (2016). "Quality \& Empowerment”, Od Practitioner Vol. 48 No. 22016.

Mike Horne. (2014). "What Is Happening With Values In Organization Development?”, Od Practitioner Vol. 46 No. 42014.

N. Clifton, R. David, O. Ehret \& D. Pickernell. (2011). “An Analysis Of Actual And Potential Clustering Structures, Stakeholder Governance Activities And Cross-Locality Linkages In The Welsh Aerospace Industry", European Planning Studies Vol. 19.

Nicoleta Valentina Florea Anisoara Duica. (2017). "Improving Communication And Relationship With Customers Using Models To Measure Their Value", Valahian Journal Of Economic Studies Volume 8 (22), Issue $1, \square 2017$.

O. Jonkeren And P. Rietveld. (2016). "Protection Of Critical Waterborne Transport Infrastructures: An Economic Review”, Transport Reviews, 2016 Vol. 36, No. 4, 437-453.

P Pegkas And C Tsamadias. (2016). "How Important Are Foreign And Domestic Investments, Exports And Human Capital For Greece's Economic Growth?”, Economic Issues, Vol. 21, Part 1.

Peter V. Miller. (2017). “Is There A Future For Surveys?”, Public Opinion Quarterly, Vol. 81, Special Issue, 2017, Pp. 205-212.

Robert Kramer. (2015). "Dialogic Organization Development: The Theory And Practice Of Transformational Change, Edited By Gervase R. Bushe And Robert J. Marshak. 2015. 436 Pages, Hardback. Oakland, Ca: Berrett-Koehler"

Sangeeta Yadav. (2014). "The Role Of Emotional Intelligence In Organization Development"

Sanjit Kumar Dash. (2017). "An Analysis Of Customer Needs And Satisfaction: Application Of Kano Model”

Sarocha Phumbua And Benny Tjahjono. (2012). "Towards Product-Service Systems Modeling: A Quest For Dynamic Behaviour And Model Parameters”, International Journal Of Production Research Vol. 50, No. 2, 15 January 2012, 425-442.

Sharon Poczter. (2018). "Business Groups In Emerging Markets: A Survey And Analysis”, Emerging Markets Finance \& Trade, 1150-1182, 2018.

Terry L. Fox. (2011). “A Systems Analysis, Design, And Development Case Study: Williams Bros. Appliances Inventory \& Point-Of-Sale System”, Journal Of The International Academy For Case Studies, Volume 17, Number 8, 2011.

Y. Yan Et Al. (2009). “The Impact Of Business Investment On Capability Exploitation And Organizational Control In International Strategic Alliances", Journal Of Change Management Vol. 9, No. 1, 49-65.

Zlatija Jelenkovic1, Lidija Barjaktarovic. (2016). "The Risk Management Functions In The Conditions Of Globalization: Case Study Of The Republic Of Serbia" 